九州大学学術情報リポジトリ

Kyushu University Institutional Repository

Environmental impact of amino acids on the release of selenate immobilized in hydrotalcite: Integrated interpretation of experimental and density-functional theory study

Wang, Mengmeng

Department of Earth Resources Engineering, Kyushu University

Akamatsu, Hirofumi

Department of Applied Chemistry, Kyushu University

Dabo, Ismai la

Department of Materials Science and Engineering, The Pennsylvania State University

Sasaki, Keiko

Department of Earth Resources Engineering, Kyushu University

ht tp://hdl. hand le. net/2324/4476141

出版情報：Chemosphere. 274 (129927)，2021-06-01. Elsevier バージョン：

権利関係: Creative Commons Attribution-NonCommercial-NoDerivatives 4.0 International 


\title{
Environmental impact of amino acids on the release of selenate immobilized in hydrotalcite: Integrated interpretation of experimental and density-functional theory study
}

\author{
Mengmeng Wang a, Hirofumi Akamatsu ${ }^{\mathrm{b}}$, Ismaila Dabo ${ }^{\mathrm{c}}$, Keiko Sasaki ${ }^{\mathrm{a}, *}$ \\ a Department of Earth Resources Engineering, Kyushu University, Fukuoka, 819-0395, Japan \\ b Department of Applied Chemistry, Kyushu University, Fukuoka, 819-0395, Japan \\ ${ }^{\mathrm{c}}$ Department of Materials Science and Engineering, The Pennsylvania State University, University Park, PA, 16802, United States
}

\section{H I G H L I G H T S}

- Effect of amino acids on the mobility of selenate in LDH was explored.

- Smaller sizes of amino acids promoted the release of selenate from LDH.

- DFT predicted the interlayer spaces of LDH after intercalation of amino acids.

- Singly stacked configuration of glycine was the most stable in $\mathrm{LDH}$.

- Cysteine suppressed the Mg dissolution from LDH.

\section{A R T I C L E I N F O}

Article history:

Received 13 October 2020

Received in revised form

26 January 2021

Accepted 7 February 2021

Available online 15 February 2021

Handling Editor: Martine Leermakers

Keywords:

Selenate

Hydrotalcite

Sorption isotherms of amino acids

Intercalation

DFT calculation

Hydrogen bond

\section{G R A P H I C A L A B S T R A C T}

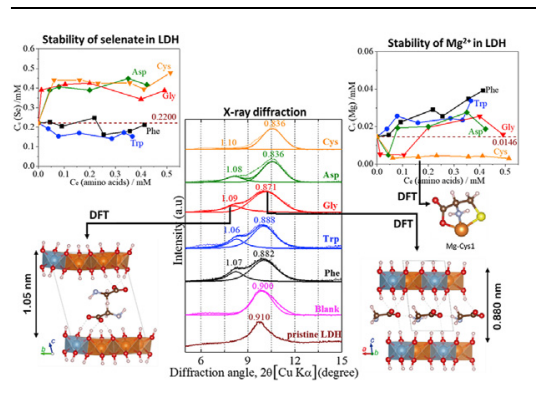

\begin{abstract}
A B S T R A C T
The environmental impact of amino acids on the release of $\mathrm{SeO}_{4}^{2-}$ immobilized into hydrotalcite $\left(\mathrm{Mg}_{2} \mathrm{Al}-\right.$ LDH) which belongs to the layered double hydroxides (LDHs) family was investigated by experimental study and the observed layer structure of hydrotalcite was verified through density-functional theory (DFT) calculations. Glycine, L-cysteine, and L-aspartic acid, which have smaller molecular sizes, can release $\mathrm{SeO}_{4}^{2-}$ largely due to intercalation, unstabilization of $\mathrm{Mg}_{2} \mathrm{Al}-\mathrm{LDH}$ and simple dissolution, while Ltryptophan and L-phenylalanine caused limited $\mathrm{SeO}_{4}^{2-}$ release due to their larger sizes and aromaticity. XRD patterns for the solid residues after intercalation of amino acids revealed that the layer distance of $\mathrm{Mg}_{2} \mathrm{Al}-\mathrm{LDH}$ was partially expanded. The main peaks and shoulder features corresponding to $d_{003}$ diffraction were well explained by DFT simulations using glycine as a model: the layer spacing of the main peak is responsible for the remaining $\mathrm{SeO}_{4}^{2-}$ and singly stacked glycine molecule and the layer spacing of the shoulder peak was well explained by doubly stacked glycine molecules. Hydrogen bonds between amino acids and hydroxyl ions in the metallic layers of $\mathrm{Mg}_{2} \mathrm{Al}-\mathrm{LDH}$ were responsible for the stable configuration of the intercalated $\mathrm{Mg}_{2} \mathrm{Al}-\mathrm{LDH}$. This study indicates potential limitations to the stability of low-level radioactive wastes of ${ }^{79} \mathrm{Se}$ in repositories which are affected by smaller molecules of amino acids released through degradation of organic matters in the pedosphere.
\end{abstract}

() 2020 The Author(s). This is an open access article under the CC BY-NC-ND license (http:// creativecommons.org/licenses/by-nc-nd/4.0/).

\footnotetext{
* Corresponding author.

E-mail addresses: wang@mine.kyushu-u.ac.jp (M. Wang), h.akamatsu@cstf. kyushu-u.ac.jp (H. Akamatsu), dabo@psu.edu (I. Dabo), keikos@mine.kyushu-u.ac. jp (K. Sasaki).
}

\section{Introduction}

${ }^{79} \mathrm{Se}$ isotope is one of the radionuclides, which is produced by 
nuclear power plants with a long half-life time of $3.27 \times 10^{5}$ years and the safe disposal has attracted worldwide attention (Jörg et al., 2010; Koilraj et al., 2017; Ferreira et al., 2019). The dominant forms are selenate $\left(\mathrm{SeO}_{4}^{2-}\right)$ and/or selenite $\left(\mathrm{SeO}_{3}^{2-}\right)$, which are more mobile in aqueous environments than cationic species due to the negative charges of the surface of silicate minerals as major constituents in the earth crust.

The burying method of radioactive wastes is dependent on the radioactivity. The low-level radioactivity wastes are applied to the relatively shallow subsurface disposal in trench and pit forms. In the trench pit disposal, the radioactive wastes are solidified in cement, covered with concrete and then buried underground at a suitable depth of geological formation. Due to the advantageous environmental and economic attributes, cement and cementitious materials including lime, fly ash, blast furnace slag, and alkalineearth metal oxides are used for the ${ }^{79}$ Se solidification (Guo et al., 2017; Sun et al., 2017; Tian et al., 2020a). Layered double hydroxides (LDHs) are some of the products in cement systems, so the formation of LDHs and immobilizing characteristics of anionic species in LDHs have been widely explored (You et al., 2001; Aimoz et al., 2012; Koilraj et al., 2018; Xu and Huang, 2019). The immobilization mechanisms of $\mathrm{SeO}_{4}^{2-}$ into LDHs mainly involve surface adsorption, co-precipitation and anionic exchange (Chubar and Szlachta, 2015; Constantino et al., 2017; Zhu et al., 2017). Addition of some additives such as zero valent iron also facilitates the immobilization of selenate in LDHs (Hu et al., 2017). However, selenate is more mobile than selenite in LDHs (Constantino et al., 2017).

There are several works which focus on the effect of natural organic matters, including microorganisms on the stabilities of radioactive species. Monitoring deep subsurface microbiota for assessment of safe long-term nuclear waste disposal has been also reviewed (White and Ringelberg, 1996). Microbes with their resistance to heat and radioactivity, if they are present and metabolically active, could have major effects on the safety of nuclear waste disposal by posing potential problems in long-term storage. Effects of organic carbons on the transportation of radioactive species and changes in chemical speciation of radioactive species (reduction) have also motivated the researchers for long years. Tokunaga et al. (2005) have reported uranium reduction in sediments in the presence of organic carbon through in-situ observation, and shown the $\mathrm{U}(\mathrm{VI})$ is reduced to $\mathrm{U}(\mathrm{IV})$ which is stabilized as $\mathrm{UO}_{2}$ affecting the mobility of radioactive uranium. Microbiological reduction and chemical reduction by phenolic groups in humic substances are suggested to involve in the transformation of $\mathrm{U}(\mathrm{VI})$ and $U(I V)$. Therefore, the natural organic substances including hummus, humic substances, sugar and protein may have threatening effects on the stability of LDHs (Murphy et al., 1992; Liang and Butler, 2010; Gao et al., 2018).

Amino acids are monomers of proteins, which are one of the most important constituents in living organisms, and the simplest model of biomolecules in organic substances in nature (Belitz et al., 2004). Amino acids belong to amphoteric compounds and possess hydrophobic and hydrophilic properties due to the amino $\left(-\mathrm{NH}_{2}\right)$ and carboxyl $(-\mathrm{COOH})$ groups. Each amino acid has side chains composed of different functional "R" groups and they can be classified into aliphatic and aromatic groups. Acid dissociation constant ( $\mathrm{pKa}$ ) values derived from amino, carboxyl, and thiol groups express the charge of the molecules under the specific $\mathrm{pH}$. Under the strongly alkaline $\mathrm{pH}$ such as cement systems, amino acid molecules are negatively charged, so they would likely be stabilized in LDHs. Although there have been several reports to focus on amino acids intercalated LDHs, they are mostly expected to have applications to predict the transportation of amino acids and biomolecules in drug delivery systems (Aisawa et al., 2004; Yuan et al., 2004) and recently to synthesize the adsorbent composites for removal of pollutant species (heavy metals and/or anionic species) in environmental remediation of the hydrosphere (Asiabi et al., 2017; Lin et al., 2018; Tran et al., 2018a, 2018b; Koilraj et al., 2019). Meanwhile, there are no reports to investigate the natural effects from biodegraded organic matters on the stability of immobilized anionic radioactive species in LDHs.

Hydrotalcite $\left(\mathrm{Mg}_{2} \mathrm{Al}-\mathrm{LDH}\right)$ is the most representative layered double hydroxide (LDH), which possesses the ability to retain anionic species including $\mathrm{SeO}_{4}^{2-}$ (You et al., 2001; Paikaray et al., 2013; Opiso et al., 2016; Tian et al., 2020b). Therefore, in the present work, we report here the effect of amino acids on the stability of incorporated selenate in hydrotalcite, which serves as a model for the chemical environment of the pedosphere. The releasing behavior of selenate accompanied with ion exchange with different amino acids were discussed by observation of water chemistry and changes in the layer spacing of $\mathrm{Mg}_{2} \mathrm{Al}-\mathrm{LDH}$ by XRD, combined with density-functional theory (DFT) predication of the relaxed configurations and coordination of amino acids in the interlayer of $\mathrm{Mg}_{2} \mathrm{Al}$ $\mathrm{LDH}$. The present work provides prospective alarms toward the radioactive waste in repositories and the environmental problems of concrete at low durability.

\section{Experimental}

\subsection{Materials}

Five amino acids, L-tryptophan ( $\operatorname{Trp}, \mathrm{C}_{11} \mathrm{H}_{12} \mathrm{~N}_{2} \mathrm{O}_{2}$ ), L-phenylalanine (Phe, $\mathrm{C}_{9} \mathrm{H}_{11} \mathrm{NO}_{2}$ ), Glycine ( $\mathrm{Gly}, \mathrm{C}_{2} \mathrm{H}_{5} \mathrm{NO}_{2}$ ), L-aspartic acid (Asp, $\mathrm{C}_{4} \mathrm{H}_{7} \mathrm{NO}_{4}$ ), L-cysteine (Cys, $\mathrm{C}_{3} \mathrm{H}_{7} \mathrm{NO}_{2} \mathrm{~S}$ ) were selected in the present work as shown in Table S1. They have different functional groups, charges, and molecular sizes. Asp includes two carboxyl groups and Cys contains one thiol group as well as one carboxyl group in one molecule, which contributes to the formation of negative charges. All of amino acids are in special grade and were purchased from Wako Chemicals (Osaka, Japan).

Inorganic chemicals including $\mathrm{Mg}\left(\mathrm{NO}_{3}\right)_{2} \cdot 6 \mathrm{H}_{2} \mathrm{O}$ (99\%), $\mathrm{Al}\left(\mathrm{NO}_{3}\right)_{3} \cdot 9 \mathrm{H}_{2} \mathrm{O}$ (98\%), $\mathrm{NaOH}(97 \%), \mathrm{Na}_{2} \mathrm{SeO}_{4}$ (97\%), $\mathrm{NaNO}_{3}$ (99\%) for the synthesis of $\mathrm{Mg}_{2} \mathrm{Al}-\mathrm{LDH}$ are in analytical grade and supplied from Wako Chemicals (Osaka, Japan). Each solution was prepared using decarbonized water which was prepared by boiling ultrapure water purged with $\mathrm{N}_{2}$ gas (99.99\%) for $2 \mathrm{~h}$.

\subsection{Synthesis of $\mathrm{Mg}_{2} \mathrm{Al}-\mathrm{LDH}\left(\mathrm{SeO}_{4}\right)$}

Firstly, $\mathrm{Mg}_{2} \mathrm{Al}-\mathrm{LDH}\left(\mathrm{NO}_{3}\right)$ was prepared through the coprecipitation method. $20 \mathrm{~mL}$ of the solution including $1 \mathrm{M} \mathrm{Mg}\left(\mathrm{NO}_{3}\right)_{2} \cdot 6 \mathrm{H}_{2} \mathrm{O}$ and $0.5 \mathrm{M} \mathrm{Al}\left(\mathrm{NO}_{3}\right)_{3} \cdot 9 \mathrm{H}_{2} \mathrm{O}$ (solution A) dropwise into $30 \mathrm{~mL} 0.33 \mathrm{M} \mathrm{NaNO}_{3}$ (solution $\mathrm{B}$ ) under vigorous stirring with the pH maintained at 10.0 using $3 \mathrm{M} \mathrm{NaOH}$. Afterward, the obtained slurries were stirred for another $30 \mathrm{~min}$ and then transferred into the Teflon vessels which were put in an Ethos Plus microwave (Milestone General, Kawasaki, Japan) oven for $5 \mathrm{~h}$ at $373 \mathrm{~K}$. Thereafter, the precipitates were collected by centrifugation at $8000 \mathrm{rpm}$ for $6 \mathrm{~min}$, washed by pure water several times and freeze-dried for $24 \mathrm{~h}$. It should be noted that the whole procedure was conducted under $\mathrm{N}_{2}$ atmosphere to minimize the contamination of carbon dioxide $\left(\mathrm{CO}_{2}\right)$.

Secondly, $1.0 \mathrm{~g}$ of the above product was suspended into $50 \mathrm{~mL}$ $41 \mathrm{mM} \mathrm{Na}_{2} \mathrm{SeO}_{4}$ and the mixture was stirred at $300 \mathrm{rpm}$ for $24 \mathrm{~h}$. This process was repeated 2 times to maximize the ion-exchange with $\mathrm{SeO}_{4}^{2-}$ in $\mathrm{Mg}_{2} \mathrm{Al}-\mathrm{LDH}\left(\mathrm{NO}_{3}\right)$. The powdery product was obtained at $\mathrm{pH} 8.0$ after going through centrifugation, washing, and drying as mentioned above. All of the procedures were conducted in a glovebox ( $95 \% \mathrm{~N}_{2}, 5 \% \mathrm{H}_{2}, \mathrm{COY}, \mathrm{M}-160$, Grass Lake, US). 
Both products were characterized by X-ray diffraction (XRD, Rigaku Ultima IV, Akishima, Japan) and elemental compositions by inductively coupled plasma optical emission spectrometry (ICPOES, Optima 8300, PerkinElmer, Boston Waltham, US) and inductively coupled plasma mass spectrometry (ICP-MS, Agilent 7500c, Santa Clara, US) after $\mathrm{HNO}_{3}$ decomposition.

\subsection{Reaction of $\mathrm{Mg}_{2} \mathrm{Al}-\mathrm{LDH}\left(\mathrm{SeO}_{4}\right)$ with amino acids}

The solutions of Trp, Phe, Gly, Asp, and Cys were prepared separately using decarbonized water in the range of $0.0-0.5 \mathrm{mM}$. According to the $\mathrm{pKa}$ values of the amine group: $\mathrm{pKa}\left(\mathrm{NH}_{3}^{+}\right)=9.13$, 9.39, 9.60, 9.90, and 10.80 for Phe, Trp, Gly, Asp, and Cys (Tables S1), respectively, the $\mathrm{pH}$ of each solution was adjusted to $10.8-11.0$ using $3 \mathrm{M} \mathrm{NaOH}$ to keep the maximum amount of negative charges. $50 \mathrm{mg}$ of the obtained $\mathrm{Mg}_{2} \mathrm{Al}-\mathrm{LDH}\left(\mathrm{SeO}_{4}\right)$ was separately added into $50 \mathrm{~mL}$ of the above amino acid solution with a solid/liquid ratio of $1 \mathrm{~g} / \mathrm{L}$. Separately, the blank solution without any amino acids was also prepared as a control. At room temperature, the suspensions were stirred for $24 \mathrm{~h}$ and filtrated using $0.2 \mu \mathrm{m}$ membrane filters to obtain the supernatant for determination of the remaining amino acids concentrations by high-performance liquid chromatography (HPLC, LC-Net II/ADC, JASCO, Hachioji, Japan), and the released Se, $\mathrm{Mg}$ and $\mathrm{Al}$ concentrations by ICP-OES and ICP-MS. It is worth noting that the $\mathrm{pH}$ adjustment and solutions transfer were all conducted in a glovebox to minimize $\mathrm{CO}_{2}$ effects.

Concentrations of amino acids were determined by HPLC LC-Net II/ADC, which is equipped with a column (Shim-pack GIST-HP C18 column, Shimadzu, Kyoto, Japan) and a UV detector (UV-2075 plus, JASCO, Hachioji, Japan). First, $0.1 \mathrm{~mL} 1.0 \mathrm{M}$ triethylamine and $0.1 \mathrm{~mL}$ $0.2 \mathrm{M}$ phenyl isothiocyanate (PITC) were mixed with $0.2 \mathrm{~mL}$ of the sample solution and standstill for $1 \mathrm{~h}$. Then, $0.4 \mathrm{~mL}$ of $n$-hexane was added and shaken by a Vortex mixer for $10 \mathrm{~s}$. Finally, $0.2 \mathrm{~mL}$ of lower-layer phase was taken and mixed with $0.8 \mathrm{~mL}$ ultra-pure water for determination (Heinrikson and Meredith, 1984; Scholze, 1985; Cohen et al., 1986; Lippincott et al., 1988; Gunawan et al., 1990). (1):

The adsorption density of each amino acid was calculated by Eq.

$q_{e}=\left(C_{0}-C_{e}\right) \cdot V / m$

where $q_{e}\left(\mathrm{mmol} \mathrm{g}^{-1}\right)$ is the amino acid sorption amount in $\mathrm{Mg}_{2} \mathrm{Al}$ $\mathrm{LDH}\left(\mathrm{SeO}_{4}\right)$ after $24 \mathrm{~h}, \mathrm{C}_{0}(\mathrm{mM})$ is the initial concentration of amino acid, $C_{e}(\mathrm{mM})$ is the equilibrium concentration of amino acid after the interaction, $V(\mathrm{~L})$ is the volume of solution and $m(\mathrm{~g})$ is the mass of $\mathrm{Mg}_{2} \mathrm{Al}-\mathrm{LDH}\left(\mathrm{SeO}_{4}\right)$. It was confirmed that the equilibrium was achieved within $24 \mathrm{~h}$

\subsection{Solid characterizations}

The solid residues were collected to provide for the determination of elemental compositions and measurements of X-ray diffraction patterns and zeta potentials.

The elemental compositions of $\mathrm{Mg}_{2} \mathrm{Al}-\mathrm{LDH}\left(\mathrm{NO}_{3}\right)$ and $\mathrm{Mg}_{2} \mathrm{Al}-$ $\mathrm{LDH}\left(\mathrm{SeO}_{4}\right)$ were estimated by digesting a specific amount of solid phase in $25 \mathrm{~mL} 5 \% \mathrm{HNO}_{3}$ to collect the solution. Nitrate $\left(\mathrm{NO}_{3}^{-}\right)$was determined by ion chromatography (IC, ICS-2100, Thermo Scientific, Waltham, US) after the sample was dissolved into $0.1 \mathrm{M} \mathrm{HCl}$. The carbon $(\mathrm{C})$, hydrogen $(\mathrm{H})$, nitrogen $(\mathrm{N})$ contents in $\mathrm{Mg}_{2} \mathrm{Al}-\mathrm{LDH}\left(\mathrm{NO}_{3}\right)$ and $\mathrm{Mg}_{2} \mathrm{Al}-\mathrm{LDH}\left(\mathrm{SeO}_{4}\right)$ were determined by a $\mathrm{CHN}$ analyzer $(\mathrm{CHN}$ MT-5, Yanaco Technical Science Co. Ltd., Tokyo, Japan). The C content was derived from incorporated carbonate caused by $\mathrm{CO}_{2}$ contamination. XRD patterns of solid samples were collected by Xray diffraction by RIGAKU Ultima IV XRD (Akishima, Japan) using Cu $\mathrm{K} \alpha$ radiation ( $40 \mathrm{kV}, 40 \mathrm{~mA}$ ) at a scanning speed of $2^{\circ} / \mathrm{min}$, and with a scanning step of $0.02^{\circ}$. Peak separation was performed by the package PeakFit software (Ver.4.12). The zeta potential of $\mathrm{Mg}_{2} \mathrm{Al}-$ $\mathrm{LDH}\left(\mathrm{SeO}_{4}\right)$ was measured by observation of the colloidal vibration current (CVC) which can be determined by electroacoustic measurement using Zetasizer NANO-ZS (Malvern Panalytical Ltd., Worcestershire, UK).

\subsection{Electronic-structure calculation}

Electronic-structure calculations using DFT were performed to figure out the stable configurations of amino acids and selenate ions in $\mathrm{LDH}$ and the energies of the ion-exchange and complexation reactions. The projector augmented-wave (PAW) method (Blöchl, 1994; Kresse and Joubert, 1999) was employed with the PBEsol exchange-correlation functional within the generalized gradient approximation (GGA) (Perdew et al., 1996, 1997, 2008) and D3 van der Waals correction (Grimme et al., 2010, 2011) as implemented in the VASP code (Kresse and Hafner, 1993a, 1993b; Kresse and Furthmüller, 1996a, 1996b). Standard PAW datasets were used with a plane-wave cutoff energy of $550 \mathrm{eV}$. The following states were treated as valence electrons: $1 \mathrm{~s}$ for $\mathrm{H} ; 2 \mathrm{~s}$ and $2 \mathrm{p}$ for $\mathrm{C}, \mathrm{N}$, and $\mathrm{O}$; $3 \mathrm{~s}$ and $3 \mathrm{p}$ for $\mathrm{Mg}$ and $\mathrm{Al} ; 4 \mathrm{~s}$ and $4 \mathrm{p}$ for Se. The lattice constants and internal coordinates were optimized until the residual stress and force converged to $0.0044 \mathrm{GPa}$ and $1 \mathrm{meV} / \mathrm{A}$, respectively. The unit cells used in this study contain a positively charged $\mathrm{Mg}_{2} \mathrm{Al}-\mathrm{LDH}$ layer $\left(\left[\mathrm{Mg}_{2} \mathrm{Al}(\mathrm{OH})_{6}\right]^{+}\right)$and deprotonated Gly monovalent anions $\left(\left[\mathrm{CH}_{2}\left(\mathrm{NH}_{2}\right)(\mathrm{COO})\right]^{-}\right)$and/or a selenate anion $\left(\mathrm{SeO}_{4}^{2-}\right)$. A wide variety of configurations of Gly and selenate ions between the LDH layers were considered for input structural models. A $4 \times 4 \times 2 k$-mesh was used according to the Monkhorst-Pack scheme (Monkhorst and Pack, 1976) for the unit cells having the composition of $\mathrm{Mg}_{2} \mathrm{Al}(\mathrm{OH})_{6} \cdot \mathrm{CH}_{2}\left(\mathrm{NH}_{2}\right)(\mathrm{COO})$. The formation energies were calculated based on the following ion-exchange reaction:

$\mathrm{Mg}_{2} \mathrm{Al}(\mathrm{OH})_{6} \cdot 0.5 \mathrm{SeO}_{4}+x \mathrm{CH}_{2}\left(\mathrm{NH}_{2}\right) \mathrm{COOH}=\mathrm{Mg}_{2} \mathrm{Al}(\mathrm{OH})_{6} \cdot x \mathrm{CH}_{2}\left(\mathrm{NH}_{2}\right)$ $\mathrm{COO} \cdot 0.5(1-x) \mathrm{SeO}_{4}+0.5 x \mathrm{H}_{2} \mathrm{SeO}_{4}$

To determine the formation energies, the total energies were independently calculated for the intercalated $\mathrm{LDH}$ with the composition of $\mathrm{Mg}_{2} \mathrm{Al}(\mathrm{OH})_{6} \cdot x \mathrm{CH}_{2}\left(\mathrm{NH}_{2}\right) \mathrm{COO} \cdot 0.5(1-x) \mathrm{SeO}_{4}(x=0$, 0.5 , and 1 ), and $\mathrm{H}_{2} \mathrm{SeO}_{4}$ and $\mathrm{CH}_{2}\left(\mathrm{NH}_{2}\right) \mathrm{COOH}$ molecules.

The association energies of $\mathrm{Mg}^{2+}$ with deprotonated amino acids ions of $\mathrm{Asp}^{2-}$ and $\mathrm{Cys}^{2-}$, are also calculated according to the following reaction:

$\mathrm{Mg}^{2+}+\mathrm{A}^{2-}=\mathrm{Mg}-\mathrm{A}$

where A is Asp and Cys, and Mg-A is a complex. During structural optimizations, the dimension of unit cells containing a single ion or a complex was fixed to be $20 \times 20 \times 20 \AA^{3}$ to keep the ions and complexes isolated. A single $k$-point sampling at the $\Gamma$ point was used. For these calculations, $\mathrm{Mg} 2 \mathrm{~s}$ and $2 \mathrm{p}$ states are also treated as valence electrons. The HSE06 functional (Heyd et al., 2003; Ge and Ernzerhof, 2006; Krukau et al., 2006) was used for these calculations because it is known to provide a better description for charge density of anions while GGA functional fail to describe negatively charged systems (Kim et al., 2011). Calculated structures for the amino acids ions and complexes were visualized using the VESTA code (Momma and Izumi, 2011). 


\section{Results and discussion}

\subsection{Characterization of $\mathrm{Mg}_{2} \mathrm{Al}-\mathrm{LDH}\left(\mathrm{SeO}_{4}\right)$}

XRD patterns for two synthesized LDHs are shown in Fig. S1(a), indicating the typical layered double hydroxide structure with 003 , 006 , and 110 reflections. Notably, the value of $d_{003}$ changed from $0.893 \mathrm{~nm}$ for $\mathrm{Mg}_{2} \mathrm{Al}-\mathrm{LDH}\left(\mathrm{NO}_{3}\right)$ to $0.910 \mathrm{~nm}$ for $\mathrm{Mg}_{2} \mathrm{Al}-\mathrm{LDH}\left(\mathrm{SeO}_{4}\right)$ (Ma et al., 2016; Constantino et al., 2017) and the FWHM at 003, 006 increased after the substitution of $\mathrm{NO}_{3}^{-}$with $\mathrm{SeO}_{4}^{2-}$, as clearly shown in Fig. S1(b). FTIR spectra also confirmed the substitution of $\mathrm{SeO}_{4}^{2-}$ with $\mathrm{NO}_{3}^{-}$in the $\mathrm{Mg}_{2} \mathrm{Al}-\mathrm{LDH}$, as shown in Fig. S1(c). The strong band at $1382 \mathrm{~cm}^{-1}$ corresponds to the $\mathrm{N}-\mathrm{O}$ vibration mode in $\mathrm{NO}_{3}^{-}$of $\mathrm{Mg}_{2} \mathrm{Al}-\mathrm{LDH}\left(\mathrm{NO}_{3}\right.$ ) (Wan et al., 2012; Xu et al., 2020). After ion-exchanged with $\mathrm{SeO}_{4}^{2-}$, the new peak at $872 \mathrm{~cm}^{-1}$ and $1369 \mathrm{~cm}^{-1}$ were assigned to $\mathrm{Se}-\mathrm{O}$ vibration and $\mathrm{C}-\mathrm{O}$ vibration mode, separately (Chubar, 2014; Chubar and Szlachta, 2015), implying some contamination of $\mathrm{CO}_{2}$ from the air could not be avoided in synthesis.

Combined the elemental compositions, obtained by IC, ICP-OES, and ICP-MS after acid digestion, with CHN analytical results of the solids, the chemical formula of the synthesized LDHs are expressed as $\mathrm{Mg}_{0.77} \mathrm{Al}_{0.38}(\mathrm{OH})_{2.32}\left(\mathrm{NO}_{3}\right)_{0.34}\left(\mathrm{CO}_{3}\right)_{0.015} \cdot 0.79 \mathrm{H}_{2} \mathrm{O}$ and $\mathrm{Mg}_{0.72} \mathrm{~A}-$ $\mathrm{l}_{0.34}(\mathrm{OH})_{2.29}\left(\mathrm{SeO}_{4}\right)_{0.142}\left(\mathrm{CO}_{3}\right)_{0.028} \cdot 1.43 \mathrm{H}_{2} \mathrm{O}(\mathrm{MW} 113.3$ ) as summarized in Table 1. The complete substitution of $\mathrm{SeO}_{4}^{2-}$ with $\mathrm{NO}_{3}^{-}$was observed, which is consistent with Fig. S1, and a small amount of carbonate $\left(\mathrm{CO}_{3}^{2-}\right)$ appeared in the $\mathrm{Mg}_{2} \mathrm{Al}-\mathrm{LDH}\left(\mathrm{SeO}_{4}\right)$ sample even though the synthetic procedure was conducted in the $\mathrm{N}_{2}$ purging glovebox. Lattice parameters and $d_{003}$ values are also listed together in Table 1. An value of $0.3044 \mathrm{~nm}$ for $\mathrm{Mg}_{2} \mathrm{Al}-\mathrm{LDH}\left(\mathrm{NO}_{3}\right)$ and $0.3038 \mathrm{~nm}$ for $\mathrm{Mg}_{2} \mathrm{Al}-\mathrm{LDH}\left(\mathrm{SeO}_{4}\right)$ was found, indicating that the microstructure of the brucite-like sheets was not changed by $\mathrm{SeO}_{4}^{2-}$ intercalation (Constantino et al., 2017).

\subsection{Interaction of amino acids with $\mathrm{Mg}_{2} \mathrm{Al}-\mathrm{LDH}\left(\mathrm{SeO}_{4}\right)$}

Without adding any amino acids, the dissolution of $\mathrm{Mg}_{2} \mathrm{Al}-$ $\mathrm{LDH}\left(\mathrm{SeO}_{4}\right)$ was observed at $\mathrm{pH}$ 11.0. To evaluate ion-exchange of amino acids with $\mathrm{SeO}_{4}^{2-}$, the released $\mathrm{SeO}_{4}^{2-}$ in the absence of amino acids caused by simple dissolution of $\mathrm{Mg}_{2} \mathrm{Al}-\mathrm{LDH}\left(\mathrm{SeO}_{4}\right)$ must be deduced. Fig. 1 presents the dissolved concentrations of Se, $\mathrm{Mg}, \mathrm{Al}$, and $\mathrm{pH}$ after $24 \mathrm{~h}$ against the equilibrated amino acids concentrations. Regarding Fig. 1(a)-(c), the dissolved amounts after $24 \mathrm{~h}$ were normalized for unit initial mass of $\mathrm{Mg}_{2} \mathrm{Al}-\mathrm{LDH}\left(\mathrm{SeO}_{4}\right)$ and shown against the equilibrated amino acids concentrations in Fig. S3. The simply released concentration of $\mathrm{SeO}_{4}^{2-}$ was $0.2215 \mathrm{mM}$ in the absence of amino acids, corresponding to $15.6 \%$ of the initially existing $\mathrm{SeO}_{4}^{2-}$ amounts in $\mathrm{Mg}_{2} \mathrm{Al}-\mathrm{LDH}\left(\mathrm{SeO}_{4}\right)$. This means that two-thirds of the original amounts of $\mathrm{SeO}_{4}^{2-}$ remain in LDH even in the case where the largest concentration of $\mathrm{SeO}_{4}^{2-}$ was released. The simply dissolved concentrations of $\mathrm{Mg}$ and $\mathrm{Al}$ were 0.0146 and $0.0200 \mathrm{mM}$ (Fig. 1(b and c)) which correspond to 2.02 and $5.88 \%$ in the original contents in LDH, respectively. This implies there is a nonstoichiometric dissolution of $\mathrm{LDH}$ with excessively enhanced dissolution of $\mathrm{Al}(\mathrm{OH})_{4}^{-}$under alkaline $\mathrm{pH}$.

Interestingly, the addition of small amounts of several amino acids (Gly, Cys, Asp with $C_{0}<0.05 \mathrm{mM}$ ) stabilized metallic ions in $\mathrm{Mg}_{2} \mathrm{Al}-\mathrm{LDH}\left(\mathrm{SeO}_{4}\right)$, but still release around $0.4 \mathrm{mM} \mathrm{SeO}_{4}^{2-}$. This suggests a small amount of Gly, Cys and Asp might function to avoid LDH dissolving. Moreover, it is notable that in the presence of Cys with $<0.5 \mathrm{mM}$ the dissolution of $\mathrm{Mg}^{2+}$ was suppressed and the behavior of Al dissolution was similar to the blank test, leading to the more significantly non-stoichiometric dissolution with excessively released $\mathrm{Al}(\mathrm{OH})_{4}^{-}$. This implies there might be some specific affinities of Cys with Mg atoms in $\mathrm{LDH}$, leaving the solid surfaces of LDH with Al deficiency. DFT simulations were performed to corroborate and further explain these findings, as discussed in section 3.4.

After reaction with Phe and Trp, the released concentration of $\mathrm{SeO}_{4}^{2-}$ was similar or lower compared with the blank test, suggesting there was almost no ion-exchange of Phe and Trp with $\mathrm{SeO}_{4}^{2-}$ and the simple dissolution contributed to $\mathrm{SeO}_{4}^{2-}$ concentrations. The above results are reflected by the interaction of negatively charged carboxylic groups and thiol groups in amino acids with positively charged $\mathrm{Mg}_{2} \mathrm{Al}-\mathrm{LDH}\left(\mathrm{SeO}_{4}\right)$. The median values of the surface charge of $\mathrm{Mg}_{2} \mathrm{Al}-\mathrm{LDH}\left(\mathrm{SeO}_{4}\right)$ were always positive in a range of pH 9.5 to 11.1 (Fig. S2), which was observed in Fig. 1(d).

Sorption isotherms of amino acids on $\mathrm{Mg}_{2} \mathrm{Al}-\mathrm{LDH}\left(\mathrm{SeO}_{4}\right)$ are expressed as shown in Fig. 2. Since the partial dissolution of $\mathrm{Mg}_{2} \mathrm{Al}-$ $\mathrm{LDH}\left(\mathrm{SeO}_{4}\right)$ accompanied as above, where dissolutionreprecipitation (D-R) mechanism might have happened when the dissolved concentrations of $\mathrm{Mg}^{2+}$ and $\mathrm{Al}(\mathrm{OH})_{4}^{-}$can contribute to the formation of $\mathrm{Mg}_{2} \mathrm{Al}-\mathrm{LDH}$ with $\mathrm{SeO}_{4}^{2-}$ and/or amino acids anions under the present pH (Xu and Lu, 2005; Takaki et al., 2016; Wan et al., 2019). This also means $\mathrm{Mg}_{2} \mathrm{Al}-\mathrm{LDH}\left(\mathrm{SeO}_{4}\right)$ is unstable in aqueous solutions, therefore, the sorption data were fitted to Freundlich isotherm instead of Langmuir isotherm. Freundlich model fitting parameters were summarized in Table 2. It is obvious that these behaviors can be divided into two groups: (i) well adsorbed (Cys, Gly, Asp), (ii) less adsorbed (Trp, Phe). As shown in Table S1, Gly is the smallest molecule, and Cys and Asp are a little bit larger than Gly and have -2 charges at $\mathrm{pH} 11.0$, while Trp and Phe have an aromatic ring and larger molecular sizes with -1 charge causing the intercalation into $\mathrm{Mg}_{2} \mathrm{Al}-\mathrm{LDH}\left(\mathrm{SeO}_{4}\right)$ more difficult. Cys, Gly, and Asp are more hydrophilic and smaller so making energetically favorable to interact with water molecules in interlayers of LDH than Phe and Trp (Khenifi et al., 2010; Silvério et al., 2013). While Asp and Cys possess -2 charges and Gly possesses - 1 charge, the sorption coefficient values $\left(K_{f}\right)$ for Asp and Cys in $\mathrm{mmol}^{(1-1 / n)} \cdot \mathrm{g}^{-1} \cdot \mathrm{L}^{1 / n}$ were much lower than twice of Gly (Table 2 ). Fig. 1 shows that Cys, Gly, and Asp caused a relatively larger concentration of $\mathrm{SeO}_{4}^{2-}$ released, indicating the release of $\mathrm{SeO}_{4}^{2-}$ is caused by not only ion-exchange but also unstabilization of LDH probably through intercalation of Cys, Gly, and Asp due to their smaller molecular sizes. The released concentration of $\mathrm{SeO}_{4}^{2-}$ was already saturated in case of Cys, Gly, and Asp, when the equilibrated concentrations of amino acids were lower than $0.1 \mathrm{mM}$ (Fig. 1(a)). As mentioned above, several factors caused the release of selenate: (1) ion-exchange with Cys, Gly, and Asp, (2) simple dissolution of $\mathrm{LDH}$, (3) unstabilization of LDH by interaction with Cys, Gly, and Asp followed by ion-exchange with carbonate. Based on the above analysis, the chemical stability of hydrotalcite after bearing $\mathrm{SeO}_{4}^{2-}$,

Table 1

Elemental compositions and cell parameters of synthesized Mg2Al-LDH(NO3) and Mg2Al-LDH(SeO4).

\begin{tabular}{|c|c|c|c|c|c|}
\hline LDHs & Chemical formula & $\mathrm{M} 2+/ \mathrm{M} 3+$ & $a(\mathrm{~nm})$ & $c(\mathrm{~nm})$ & $d 003(\mathrm{~nm})$ \\
\hline Mg2Al-LDH(NO3) & $\begin{array}{l}\mathrm{Mg} 0.77 \mathrm{Al0} 0.38(\mathrm{OH}) 2.32(\mathrm{NO} 3) 0.34 \\
(\mathrm{CO} 3) 0.015 \cdot 0.79 \mathrm{H} 2 \mathrm{O}\end{array}$ & 2.03 & 0.3044 & 2.6779 & 0.893 \\
\hline Mg2Al-LDH(SeO4) & $\begin{array}{l}\mathrm{Mg} 0.72 \mathrm{Al0} 34(\mathrm{OH}) 2.29(\mathrm{SeO} 4) 0.142 \\
(\mathrm{CO} 3) 0.028 \cdot 1.43 \mathrm{H} 2 \mathrm{O}\end{array}$ & 2.12 & 0.3038 & 2.6727 & 0.910 \\
\hline
\end{tabular}



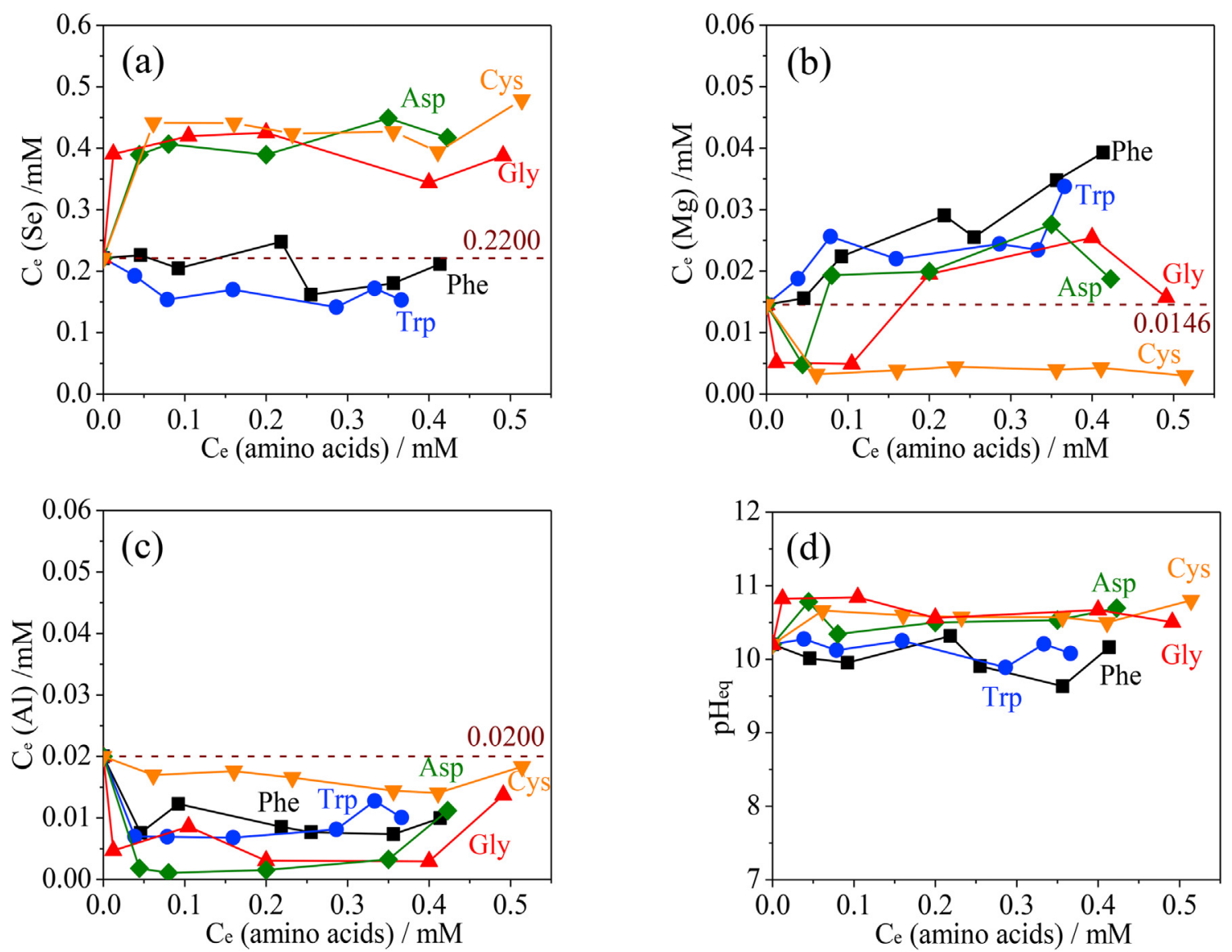

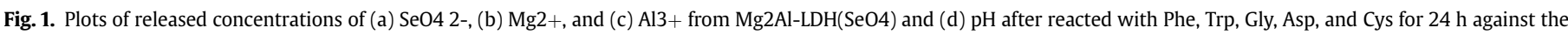
equilibrated concentrations of amino acids.

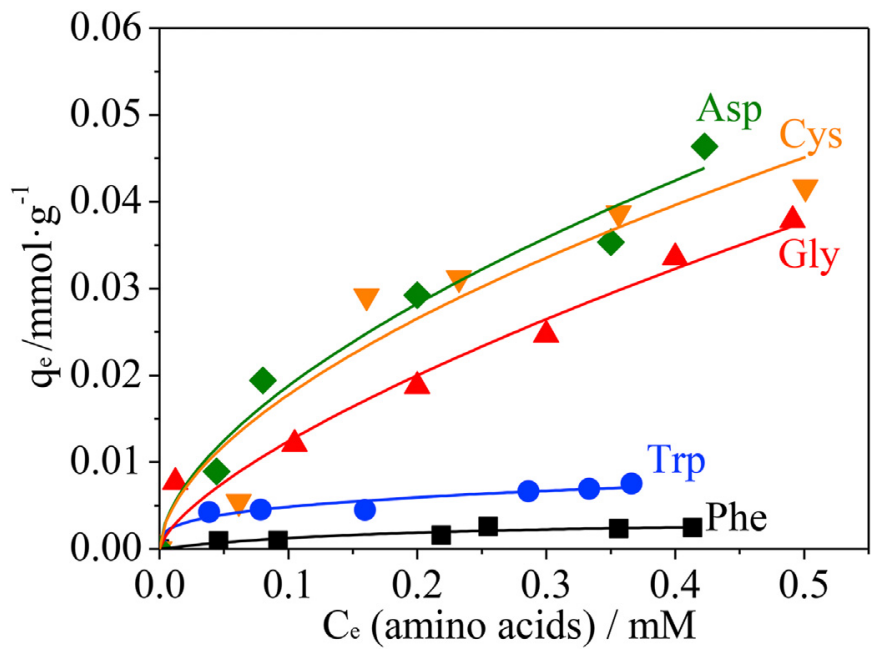

Fig. 2. Sorption isotherms of Phe ( $\boldsymbol{\square})$, Trp ( $)$, Gly ( $\mathbf{\Delta})$, Asp ( $\bullet$ ), and Cys $(\nabla)$ onto $\mathrm{Mg} 2 \mathrm{Al}-\mathrm{LDH}(\mathrm{SeO} 4)$. Solid lines indicate the fittings to Freundlich isotherms.

which can be affected by competitive anions, $\mathrm{pH}$, and temperature, becoming an important consideration in a practical circumstance (Constantino et al., 2017; Chubar, 2018). The released amount of selenate, magnesium, and aluminum from $\mathrm{Mg}_{2} \mathrm{Al}-\mathrm{LDH}\left(\mathrm{SeO}_{4}\right)$ into solution in the presence of Gly, Asp, and Cys may raise the risk in
Table 2

Fitting parameters of Freundlich isotherms in sorption of different amino acids on $\mathrm{Mg} 2 \mathrm{Al}-\mathrm{LDH}(\mathrm{SeO} 4)$.

\begin{tabular}{llll}
\hline & $K f$ & $N$ & $R^{2}$ \\
\hline L-phenylalanine & 0.0040 & 1.96 & 0.9146 \\
L-tryptophan & 0.0095 & 3.42 & 0.9571 \\
Glycine & 0.0607 & 1.44 & 0.9732 \\
L-aspartic & 0.0728 & 1.70 & 0.9738 \\
L-cysteine & 0.0673 & 1.73 & 0.9241 \\
\hline
\end{tabular}

the radioactive anionic pollutant treatment in the practical soil or wastewater. Of note is in the real environment, there are so many organic acids including different molecule sizes, structures as well as functional groups, which may significantly affect the ionexchange ability with $\mathrm{SeO}_{4}^{2-}$ in hydrotalcite. Therefore, detailed interaction information of amino acids with $\mathrm{SeO}_{4}^{2-}$ is necessary.

\subsection{Characterization of the solid residues after reaction of amino acids with $\mathrm{Mg}_{2} \mathrm{Al}-\mathrm{LDH}\left(\mathrm{SeO}_{4}\right)$}

The XRD patterns of the pristine $\mathrm{Mg}_{2} \mathrm{Al}-\mathrm{LDH}\left(\mathrm{SeO}_{4}\right)$ and the solid residues after react without/with $0.5 \mathrm{mM}$ amino acids are shown in Fig. 3(a). For the blank experiment, the $d_{003}$ value of solid residues is $0.900 \mathrm{~nm}$ which is similar to the pristine value of $0.910 \mathrm{~nm}$ (Fig. 3(b)). The broadening of $d_{003}$ was caused by the simple dissolution of $\mathrm{Mg}_{2} \mathrm{Al}-\mathrm{LDH}\left(\mathrm{SeO}_{4}\right)$. When amino acids were added, $\mathrm{Mg}_{2} \mathrm{Al}-\mathrm{LDH}\left(\mathrm{SeO}_{4}\right)$ is still the dominant phase, because two-thirds of selenate were still present at least in $\mathrm{Mg}_{2} \mathrm{Al}-\mathrm{LDH}$. As shown in 
(a)

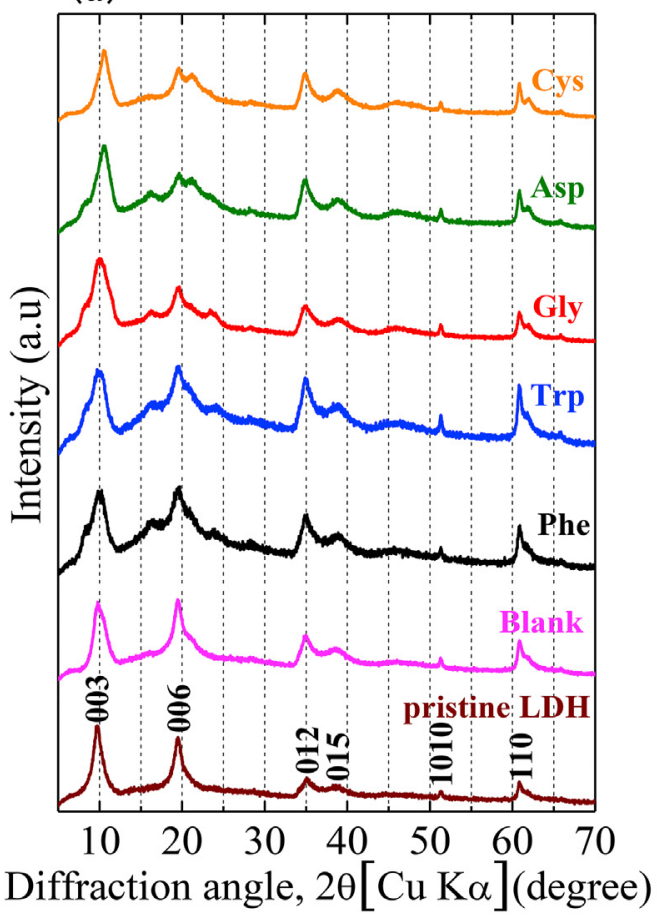

(b)

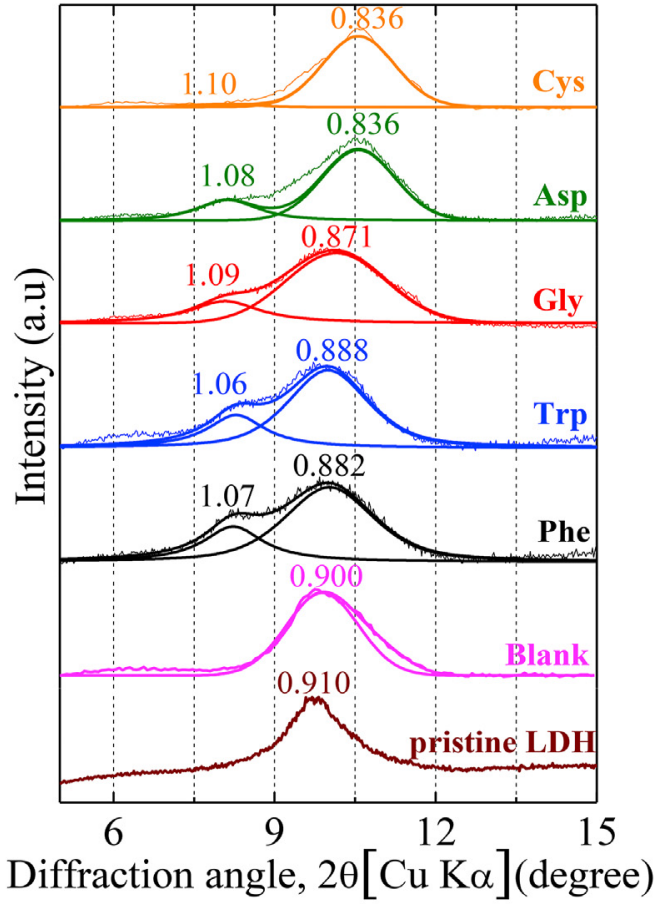

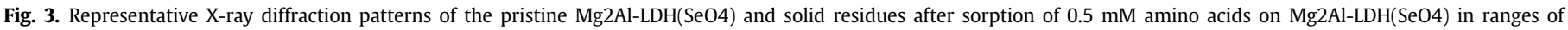
diffraction angle $(2 \theta)$ of (a) $5^{\circ}-70^{\circ}$, and (b) $5^{\circ}-15^{\circ}$. Blank means no amino acids.

Fig. 3(b), peak separation revealed that two $d_{003}$ values appeared around $1.07-1.10 \mathrm{~nm}$ of shoulder peaks and $0.836-0.882 \mathrm{~nm}$ of main peaks. This indicates $\mathrm{Mg}_{2} \mathrm{Al}-\mathrm{LDH}\left(\mathrm{SeO}_{4}\right)$ can be expandable by the intercalation with amino acids, which was not observed in $\mathrm{Zn}_{2} \mathrm{Al}-\mathrm{LDH}\left(\mathrm{SeO}_{4}\right)$ under the same condition (unpublished), probably different attraction force depending on the metal combination in LDH.

\subsection{First-principles computational analysis}

We have selected one model of the reacted $\mathrm{Mg}_{2} \mathrm{Al}-\mathrm{LDH}\left(\mathrm{SeO}_{4}\right)$ with glycine ( $\mathrm{Gly}, \mathrm{C}_{2} \mathrm{H}_{5} \mathrm{NO}_{2}$ ) to confirm the stable configurations of Gly after intercalation into $\mathrm{Mg}_{2} \mathrm{Al}-\mathrm{LDH}\left(\mathrm{SeO}_{4}\right)$, since Gly is the simplest amino acid and has the smallest molecular size, furthermore, it caused the layer distance of LDH partially expanded as shown in Fig. 3.

Fig. 4 illustrates the representative optimized structures of the intercalated $\mathrm{LDHs}, \mathrm{Mg}_{2} \mathrm{Al}-\mathrm{LDH}\left(\mathrm{SeO}_{4}\right), \mathrm{Mg}_{2} \mathrm{Al}-\mathrm{LDH}\left(\mathrm{SeO}_{4}, \mathrm{Gly}\right)$, and $\mathrm{Mg}_{2} \mathrm{Al}-\mathrm{LDH}(\mathrm{Gly})$ with the composition of $\mathrm{Mg}_{2} \mathrm{Al}(\mathrm{OH})_{6} \cdot \mathrm{xCH}_{2}\left(\mathrm{NH}_{2}\right)$ $\mathrm{COO} \cdot 0.5(1-x) \mathrm{SeO}_{4}(x=0,0.5$, and 1 , respectively). Fig. 5(a) plots the formation energies for the ion-exchange reaction, defined in Eq. (2), against the Gly concentration $x$. The solid line indicates a convex hull, which connects the lowest formation-energy points for each of the compositions. The convex hull falls to the right, indicating that $\mathrm{Gly}^{-}$can be readily exchanged with $\mathrm{SeO}_{4}^{2-}$. A close look at the optimized structures shown in Fig. 4 reveals that the oxide ions of both anionic molecules form hydrogen bonds to the protons of the LDH layers, and/or to those of the molecules leading to intermolecular interactions. The configurations of the molecules are relevant to the formation of hydrogen bonds. Fig. 5(b) presents the correlation between the formation energies and the number of hydrogen bonds per a formula unit $\mathrm{Mg}_{2} \mathrm{Al}(\mathrm{OH})_{6} \cdot x \mathrm{CH}_{2}\left(\mathrm{NH}_{2}\right)$ $\mathrm{COO} \cdot 0.5(1-x) \mathrm{SeO}_{4}$. Here, the $\mathrm{O}-\mathrm{H}$ bonds that are longer than $1.6 \AA$ and shorter than $2.1 \AA$ A are regarded as hydrogen bonds. The intercalated LDHs tend to be more stable with an increase in the number of hydrogen bonds. Fig. 5(c) plots the formation energies against the interlayer spacing. The interlayer spacing of the pristine $\mathrm{Mg}_{2} \mathrm{Al}-$ $\mathrm{LDH}\left(\mathrm{SeO}_{4}\right)(x=0)$ is about $8.2 \AA$, and that of $\mathrm{Mg}_{2} \mathrm{Al}-\mathrm{LDH}\left(\mathrm{SeO}_{4}, \mathrm{Gly}\right)$ $(x=0.5)$ ranges from 8.1 to $8.7 \AA$. Thus, there is no significant change in interlayer spacing between $x=0$ and 0.5 . Interestingly, the $\mathrm{Mg}_{2} \mathrm{Al}$-LDH (Gly) $(x=1)$ is classified into two groups in terms of interlayer spacing: one group with short interlayer spacing ranging from 7.6 to $8.8 \AA$ and the other group with long interlayer spacing ranging from 9.9 to $10.5 \AA$, which is in good agreement with the low-angle shoulder peak of 003 diffractions (Fig. 3(b)). In the former group, the Gly molecules are single stacked between the LDH layers as seen in Fig. 4(c). On the other hand, the latter group has doubly stacked Gly molecules sandwiched by LDH layers as seen in Fig. 4(d). The formation energies of the $\mathrm{Mg}_{2} \mathrm{Al}-\mathrm{LDH}(\mathrm{Gly})$ with doubly stacked Gly molecules are much higher than those of the $\mathrm{Mg}_{2} \mathrm{Al}-\mathrm{LDH}(\mathrm{Gly})$ with singly stacked Gly molecules. This is because the doubly stacked Gly molecules can form hydrogen bonds only to the protons in one side of the LDH layers, resulting in a smaller number of hydrogen bonds compared to the singly stacked Gly molecules, which can produce hydrogen bonds to the protons in both sides of the LDH layers. The $\mathrm{Mg}_{2} \mathrm{Al}-\mathrm{LDH}(\mathrm{Gly})$ with doubly stacked Gly molecules has negative formation energies and therefore can be kinetically stabilized to be responsible for the observed lattice expansion by the ion-exchange.

It was suggested that there is a strong affinity of Cys with $\mathrm{Mg}$ than other amino acids, since $\mathrm{Mg}$ was stabilized in solid phase in the presence of Cys (Fig. 1(b)) and no shoulder peaks appeared in XRD pattern for the solid residues after reaction with Cys (Fig. 3(b)). To confirm the strong affinity between Cys and $\mathrm{Mg}$ from first principles, two structural models of Mg-Cys complexes were created as shown in Fig. S4, as well as structural models of 
(a) $x=0, E_{\text {form }}=0 \mathrm{~kJ} / \mathrm{mol}, d=8.20 \AA$

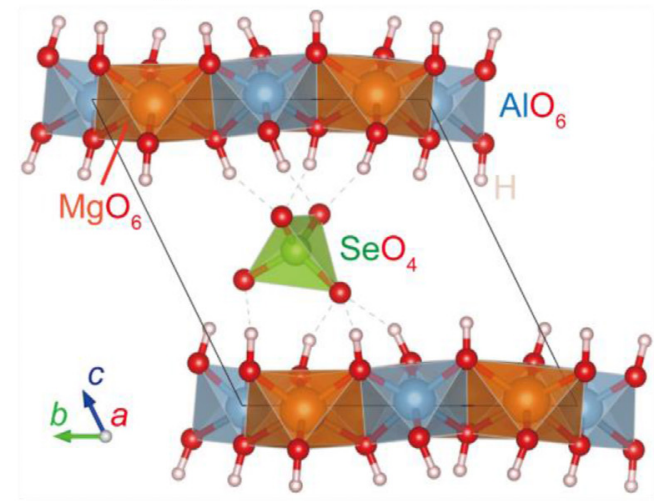

(c) $x=1, E_{\text {form }}=-83.6 \mathrm{~kJ} / \mathrm{mol}, d=7.65 \AA$

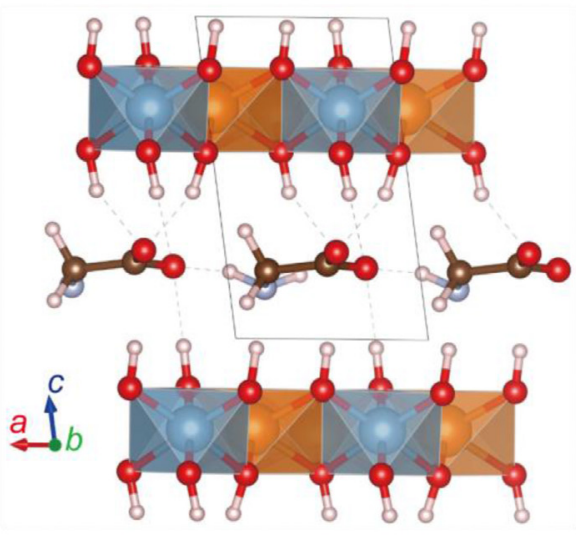

(b) $x=0.5, E_{\text {form }}=-34.5 \mathrm{~kJ} / \mathrm{mol}, d=8.36 \AA$

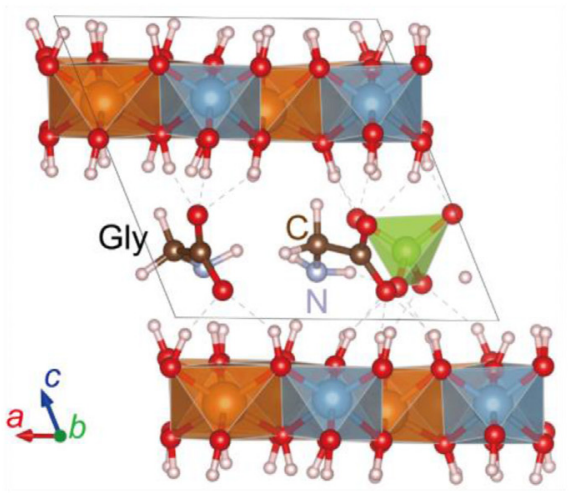

(d) $x=1, E_{\text {form }}=-15.7 \mathrm{~kJ} / \mathrm{mol}, d=10.19 \AA$

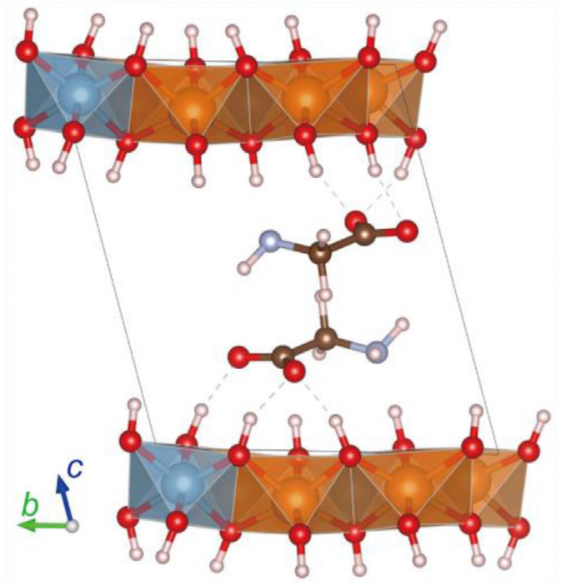

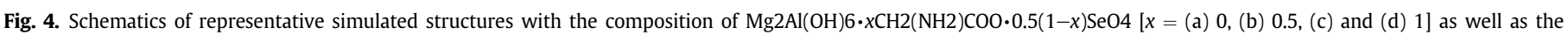
formation energy, Eform, and interlayer spacing, $d$. The dashed lines indicate hydrogen bonds.

deprotonated amino acids ions of $\mathrm{Asp}^{2-}$ and $\mathrm{Cys}^{2-}$. For comparison, a model of the Mg-Asp complex was also added for calculation of the formation energy. First, formation energies for two configurations of Mg-Cys complexes were derived from Eq. (3) to compare, where $\mathrm{Mg}$ atom is coordinated by one $\mathrm{O}$ atom from the carboxyl group, $\mathrm{S}$ atom from thiol group, and $\mathrm{N}$ atom of the amino group (Mg-Cys1 in Fig. S4(c)), and Mg atom is coordinated by two $\mathrm{O}$ atoms from carboxyl group and $\mathrm{S}$ atom from thiol group (Mg-Cys2 in Fig. S4(d)). The formation energies were $-2522.2 \mathrm{~kJ} / \mathrm{mol}$ for the former and $-2447.7 \mathrm{~kJ} / \mathrm{mol}$ for the latter. The more stable configuration of Mg-Cys1 (Fig. S4(c)) is quite similar to the previously reported model (Shankar et al., 2011). For comparison with Asp, as a representative example which showed the similar trend with other amino acids in Fig. 1(b and c), the formation energy of Mg-Cys1 was smaller than that of Mg-Asp complex (Mg-Asp in Fig. S4(e)) which was $-2481.0 \mathrm{~kJ} / \mathrm{mol}$. This suggests there is a specific affinity between Cys and Mg in a form of Mg-Cys1. Our calculations imply that the distribution of electron densities of Cys molecule tends to stabilize only $\mathrm{Mg}$ on the surface of $\mathrm{LDH}$ specifically releasing $\mathrm{Al}(\mathrm{OH})_{4}^{-}$ and selenate to the solution. This phenomenon should happen on the surface of LDH. Due to the strongly bound Cys with Mg atoms on the surface of LDH, the doubly stacked configuration of Cys in LDH interlayer is unlikely to happen in XRD pattern for the solid residues after reaction (Fig. 3(b)). This effect of Cys may also help selenate immobilization.

\section{Conclusions}

The effect of amino acids on unstabilization of selenate in $\mathrm{Mg}_{2} \mathrm{Al}-\mathrm{LDH}\left(\mathrm{SeO}_{4}\right)$ was studied by experimental analysis integrated with DFT modeling. The released amount of $\mathrm{SeO}_{4}^{2-}$ from $\mathrm{Mg}_{2} \mathrm{Al}-$ $\mathrm{LDH}\left(\mathrm{SeO}_{4}\right)$ in the absence of amino acids corresponded to $15.6 \%$ of the initially existing $\mathrm{SeO}_{4}^{2-}$ in the solids. Gly, Asp, and Cys promoted the release of $\mathrm{SeO}_{4}^{2-}$ by ion-exchange and unstabilization of $\mathrm{LDH}$ during the intercalation process of Gly, Asp and Cys. Through the intercalation, amino acids expanded the interlayer spacing of $\mathrm{Mg}_{2} \mathrm{Al}-\mathrm{LDH}\left(\mathrm{SeO}_{4}\right)$ to $1.07-1.10 \mathrm{~nm}$ except for Cys, but $\mathrm{Mg}_{2} \mathrm{Al}-$ $\mathrm{LDH}\left(\mathrm{SeO}_{4}\right)$ phase still is dominant. The DFT simulation using Gly as a model revealed that the singly stacked Gly was the most stable configuration and the layer spacing expansion of LDH was caused by the doubly stacked configuration of Gly. The intercalated LDHs tend to be more stable with increase in the number of hydrogen bonds between $\mathrm{H}$ atoms in metallic layers of $\mathrm{LDH}$ and $\mathrm{O}$ atoms in selenate and/or carboxyl groups in Gly. Notably, the dissolution of $\mathrm{Mg}^{2+}$ was suppressed by complexation with thiol, carboxyl, and amine groups in Cys which was verified by the formation energy calculated from DFT. The strong affinity of Cys with Mg might contribute to destabilizing the surface structure of LDH releasing not only $\mathrm{Al}(\mathrm{OH})_{4}^{-}$but also $\mathrm{SeO}_{4}^{2-}$. This work raises important environmental questions regarding the transportation and immobilization of anionic species of low-level radionuclide wastes in repositories, where anionic amino acids of smaller molecular size 

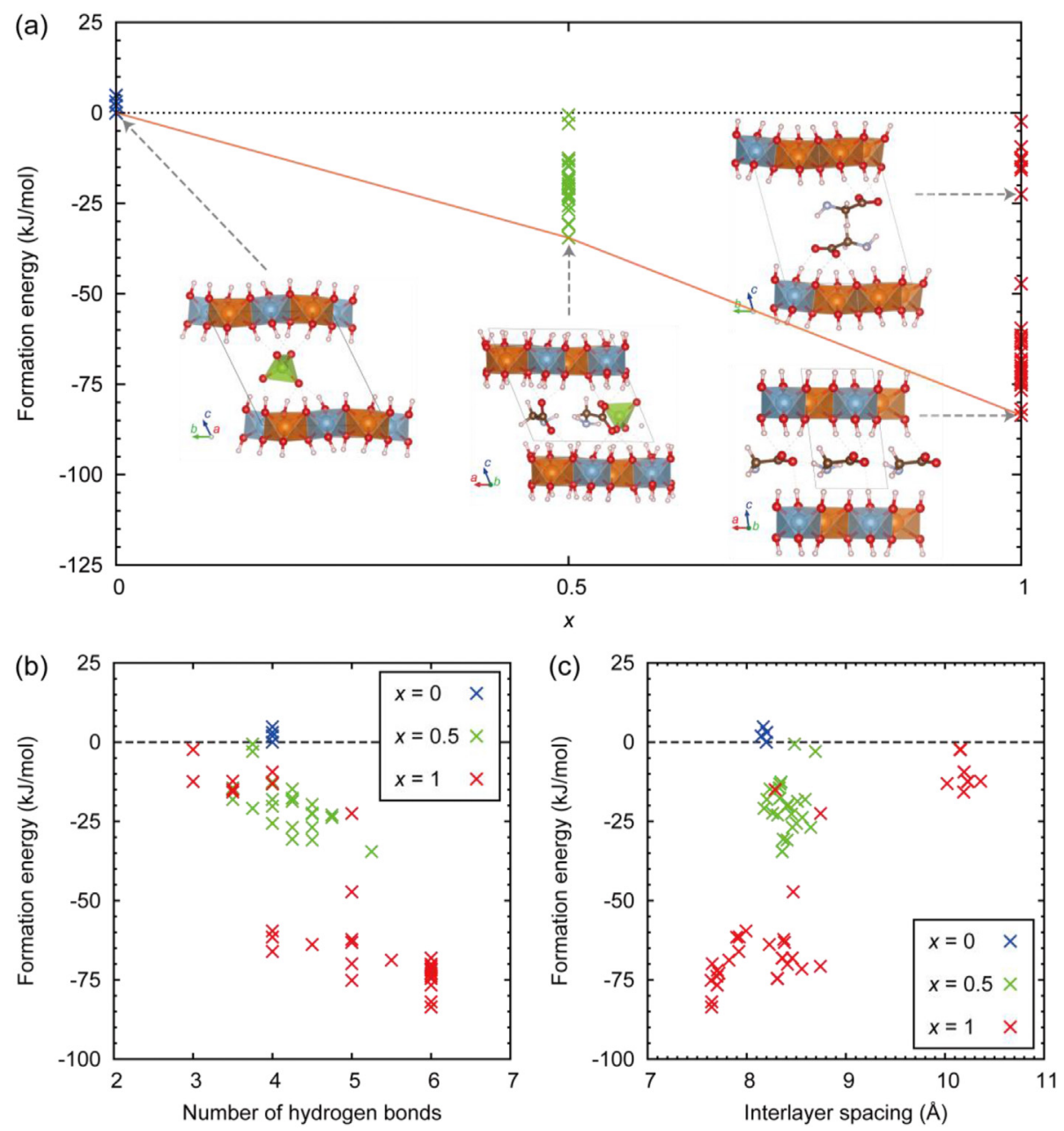

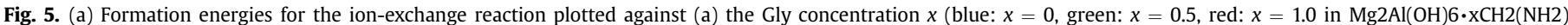

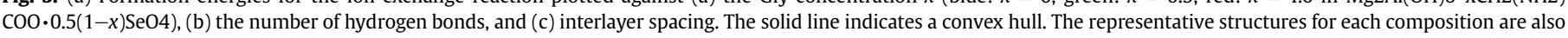
displayed in the inset. (For interpretation of the references to colour in this figure legend, the reader is referred to the Web version of this article.)

can potentially intercalate. Engineering countermeasures are necessary to stabilize selenate using, for example, barriers such as iron minerals, especially when the concentration of selenate is relatively high in the radioactive wastes.

\section{Credit author statements}

Mengmeng Wang; Writing - original draft, Data curation, Methodology, Validation, Resources, Hirofumi Akamatsu; Writing - original draft, Methodology, Software, Investigation, Validation, Visualization, Ismaila Dabo; Writing - review \& editing, Keiko Sasaki; Conceptualization, Methodology, Writing - review \& editing, Funding acquisition, Supervision.

\section{Declaration of competing interest}

The authors declare that they have no known competing financial interests or personal relationships that could have appeared to influence the work reported in this paper.

\section{Acknowledgments}

Financial supports were provided to KS by Japan Society for the Promotion of Science (JSPS) KAKENHI research grants
(JP19H00883) and Kyushu University Progress 100 (Invitation program for top global researchers) Strategic partnership acceleration (FY2020-2022) and to WM by the China Scholarship Council (201806350035). ICP-MS measurement was performed at Advanced Analytical Center in Kyushu University. ID acknowledges support by the DMREF and INFEWS programs of the U.S. National Science Foundation under Grant DMREF-1729338. The computation was partially carried out using computer resources from the Research Institute for Information Technology at Kyushu University.

\section{Appendix A. Supplementary data}

Supplementary data to this article can be found online at https://doi.org/10.1016/j.chemosphere.2021.129927.

\section{References}

Aimoz, L., Wieland, E., Taviot-Guého, C., Dähn, R., Vespa, M., Churakov, S.V., 2012. Structural insight into iodide uptake by AFm phases. Environ. Sci. Technol. 46, 3874-3881.

Aisawa, S., Kudo, H., Hoshi, T., Takahashi, S., Hirahara, H., Umetsu, Y., Narita, E., 2004 Intercalation behavior of amino acids into $\mathrm{Zn}$-Al-layered double hydroxide by calcination-rehydration reaction. J. Solid State Chem. 177, 3987-3994.

Asiabi, H., Yamini, Y., Shamsayei, M., 2017. Highly selective and efficient removal of arsenic (V), chromium (VI) and selenium (VI) oxyanions by layered double hydroxide intercalated with zwitterionic glycine. J. Hazard Mater. 339, 239-247. 
Belitz, H.-D., Grosch, W., Schieberle, P., 2004. Amino acids, peptides, proteins. Food Chem. 8-91.

Blöchl, P.E., 1994. Projector augmented-wave method. Phys. Rev. B 50, 17953.

Chubar, N., 2014. EXAFS and FTIR studies of selenite and selenate sorption by alkoxide-free sol-gel generated $\mathrm{Mg}-\mathrm{Al}-\mathrm{CO}_{3}$ layered double hydroxide with very labile interlayer anions. J. Mater. Chem. 2, 15995-16007.

Chubar, N., Szlachta, M., 2015. Static and dynamic adsorptive removal of selenite and selenate by alkoxide-free sol-gel-generated $\mathrm{Mg}-\mathrm{Al}-\mathrm{CO}_{3}$ layered double hydroxide: effect of competing ions. Chem. Eng. J. 279, 885-896.

Chubar, N., 2018. The influence of sulfate on selenate sorption on $\mathrm{Mg}-\mathrm{Al}-\mathrm{CO}_{3}$ layered double hydroxides prepared by fine inorganic sol-gel synthesis studied by X-ray photoelectron spectroscopy. Appl. Surf. Sci. 459, 281-291.

Cohen, S.A., Bidlingmeyer, B.A., Tarvin, T.L., 1986. PITC derivatives in amino acid analysis. Nature 320, 769-770.

Constantino, L.V., Quirino, J.N., Monteiro, A.M., Abrão, T., Parreira, P.S., Urbano, A., Santos, M.J., 2017. Sorption-desorption of selenite and selenate on Mg-Al layered double hydroxide in competition with nitrate, sulfate and phosphate. Chemosphere 181, 627-634.

Ferreira, E.G., Marumo, J.T., Franco, M.K., Yokaichiya, F., Vicente, R., 2019. 10000 years cement-Can hydrated cement last as much as long-lived radionuclides? Cement Concr. Compos. 103, 339-352.

Gao, Z., Sasaki, K., Qiu, X., 2018. Structural memory effect of Mg-Al and Zn-Al layered double hydroxides in the presence of different natural humic acids: process and mechanism. Langmuir 34, 5386-5395.

Ge, H.J.S., Ernzerhof, M., 2006. Erratum:"Hybrid functionals based on a screened Coulomb potential"[J. Chem. Phys. 118, 8207 (2003)]. J. Chem. Phys. 124, 219906.

Grimme, S., Antony, J., Ehrlich, S., Krieg, H., 2010. A consistent and accurate ab initio parametrization of density functional dispersion correction (DFT-D) for the 94 elements H-Pu. J. Chem. Phys. 132, 154104.

Grimme, S., Ehrlich, S., Goerigk, L., 2011. Effect of the damping function in dispersion corrected density functional theory. J. Comput. Chem. 32, 1456-1465.

Gunawan, S., Walton, N.Y., Treiman, D.M., 1990. High-performance liquid chromatographic determination of selected amino acids in rat brain by precolumn derivatization with phenylisothiocyanate. J. Chromatogr. A 503, 177-187.

Guo, B., Sasaki, K., Hirajima, T., 2017. Solidification of ettringite after uptaking selenate as a surrogate of radionuclide in glass-ceramics by using industrial byproducts. J. Mater. Sci. 52, 12999-13011.

Heinrikson, R.L., Meredith, S.C., 1984. Amino acid analysis by reverse-phase highperformance liquid chromatography: precolumn derivatization with phenylisothiocyanate. Anal. Biochem. 136, 65-74.

Heyd, J., Scuseria, G.E., Ernzerhof, M., 2003. Hybrid functionals based on a screened Coulomb potential. J. Chem. Phys. 118, 8207-8215.

Hu, B., Ye, F., Jin, C., Ma, X., Huang, C., Sheng, G., Ma, J., Wang, X., Huang, Y., 2017. The enhancement roles of layered double hydroxide on the reductive immobilization of selenate by nanoscale zero valent iron: macroscopic and microscopic approaches. Chemosphere 184, 408-416.

Jörg, G., Bühnemann, R., Hollas, S., Kivel, N., Kossert, K., Van Winckel, S., Gostomski, C.L.v., 2010. Preparation of radiochemically pure ${ }^{79} \mathrm{Se}$ and highly precise determination of its half-life. Appl. Radiat. Isot. 68, 2339-2351.

Khenifi, A., Derriche, Z., Mousty, C., Prévot, V., Forano, C., 2010. Adsorption of glyphosate and glufosinate by $\mathrm{Ni}_{2} \mathrm{AlNO}_{3}$ layered double hydroxide. Appl. Clay Sci. 47 (3-4), 362-371.

Kim, M.-C., Sim, E., Burke, K., 2011. Communication: avoiding unbound anions in density functional calculations. J. Chem. Phys. 134, 171103.

Koilraj, P., Kalusulingam, R., Sasaki, K., 2019. Arginine and lysine-functionalized layered double hydroxides as efficient sorbents for radioactive $\mathrm{Co}^{2+}$ removal by chelate-facilitated immobilization. Chem. Eng. J. 374, 359-369.

Koilraj, P., Kamura, Y., Sasaki, K., 2017. Carbon-dot-decorated layered double hydroxide nanocomposites as a multifunctional environmental material for coimmobilization of $\mathrm{SeO}_{4}^{2-}$ and $\mathrm{Sr}^{2+}$ from aqueous solutions. ACS Sustain. Chem. Eng. 5, 9053-9064.

Koilraj, P., Kamura, Y., Sasaki, K., 2018. Synergetic co-immobilization of $\mathrm{SeO}_{4}^{2-}$ and $\mathrm{Sr}^{2+}$ from aqueous solution onto multifunctional graphene oxide and carbondot based layered double hydroxide nanocomposites and their mechanistic investigation. J. Mater. Chem. 6, 10008-10018.

Kresse, G., Furthmüller, J., 1996a. Efficiency of ab-initio total energy calculations for metals and semiconductors using a plane-wave basis set. Comput. Mater. Sci. 6, 15-50.

Kresse, G., Furthmüller, J., 1996b. Efficient iterative schemes for ab initio totalenergy calculations using a plane-wave basis set. Phys. Rev. B 54, 11169.

Kresse, G., Hafner, J., 1993a. Ab initio molecular dynamics for liquid metals. Phys. Rev. B 47, 558 .

Kresse, G., Hafner, J., 1993b. Ab initio molecular dynamics for open-shell transition metals. Phys. Rev. B 48, 13115.

Kresse, G., Joubert, D., 1999. From ultrasoft pseudopotentials to the projector augmented-wave method. Phys. Rev. B 59, 1758.

Krukau, A.V., Vydrov, O.A., Izmaylov, A.F., Scuseria, G.E., 2006. Influence of the exchange screening parameter on the performance of screened hybrid functionals. J. Chem. Phys. 125, 224106.

Liang, X., Butler, E.C., 2010. Effects of natural organic matter model compounds on the transformation of carbon tetrachloride by chloride green rust. Water Res. 44, 2125-2132.

Lin, S.T., Tran, H.N., Chao, H.P., Lee, J.F., 2018. Layered double hydroxides intercalated with sulfur-containing organic solutes for efficient removal of cationic and oxyanionic metal ions. Appl. Clay Sci. 162, 443-453.

Lippincott, S.E., Friedman, A.L., Siegel, F.L., Pityer, R.M., Chesney, R.W., 1988. HPLC analysis of the phenylisothiocyanate (PITC) derivatives of taurine from physiologic samples. J. Am. Coll. Nutr. 7, 491-497.

Ma, L., Wang, Q., Islam, S.M., Liu, Y., Ma, S., Kanatzidis, M.G., 2016. Highly selective and efficient removal of heavy metals by layered double hydroxide intercalated with the MoS42-ion. J. Am. Chem. Soc. 138, 2858-2866.

Momma, K., Izumi, F., 2011. VESTA 3 for three-dimensional visualization of crystal, volumetric and morphology data. J. Appl. Crystallogr. 44, 1272-1276.

Monkhorst, H.J., Pack, J.D., 1976. Special points for Brillouin-zone integrations. Phys. Rev. B 13, 5188.

Murphy, E.M., Zachara, J.M., Smith, S.C., Phillips, J.L., 1992. The sorption of humic acids to mineral surfaces and their role in contaminant binding. Sci. Total Environ. 117, 413-423.

Opiso, E.M., Sato, T., Yoneda, T., 2016. Immobilization of selenium by Mg-bearing minerals and its implications for selenium removal from contaminated water and wastewater. Appl. Clay Sci. 123, 121-128.

Paikaray, S., Hendry, M.J., Essilfie-Dughan, J., 2013. Controls on arsenate, molybdate, and selenate uptake by hydrotalcite-like layered double hydroxides. Chem. Geol. 345, 130-138.

Perdew, J., Burke, K., Ernzerhof, M., 1997. Coupling-constant dependence of atomization energies. Phys. Rev. Lett. 78, 1396.

Perdew, J.P., Burke, K., Ernzerhof, M., 1996. Generalized gradient approximation made simple. Phys. Rev. Lett. 77, 3865.

Perdew, J.P., Ruzsinszky, A., Csonka, G.I., Vydrov, O.A., Scuseria, G.E., Constantin, L.A., Zhou, X., Burke, K., 2008. Restoring the density-gradient expansion for exchange in solids and surfaces. Phys. Rev. Lett. 100, 136406.

Scholze, H., 1985. Determination of phenyltiocarbamyl amino acids by reversedphase high-performance liquid chromatography. J. Chromatogr. A 350, $453-460$.

Shankar, R., Kolandaivel, P., Senthilkumar, L., 2011. Interaction studies of cysteine with $\mathrm{Li}^{+}, \mathrm{Na}^{+}, \mathrm{K}^{+}, \mathrm{Be}^{2+}, \mathrm{Mg}^{2+}$, and $\mathrm{Ca}^{2+}$ metal cation complexes. J. Phys. Org. Chem. 24, 553-567.

Silvério, F., Dos Reis, M.J., Tronto, J., Valim, J.B., 2013. Sorption of aspartic and glutamic aminoacids on calcined hydrotalcite. SpringerPlus 2, 211.

Sun, W., Renew, J.E., Zhang, W., Tang, Y., Huang, C.H., 2017. Sorption of Se (IV) and Se (VI) to coal fly ash/cement composite: effect of $\mathrm{Ca}^{2+}$ and high ionic strength. Chem. Geol. 464, 76-83.

Takaki, Y., Qiu, X., Hirajima, T., Sasaki, K., 2016. Removal mechanism of arsenate by bimetallic and trimetallic hydrocalumites depending on arsenate concentration. Appl. Clay Sci. 134, 26-33.

Tian, Q., Guo, B., Chuaicham, C., Sasaki, K., 2020a. Mechanism analysis of selenium (VI) immobilization using alkaline-earth metal oxides and ferrous salt. Chemosphere 248, 126123.

Tian, Q., Guo, B., Sasaki, K., 2020b. Immobilization mechanism of Se oxyanions in geopolymer: effects of alkaline activators and calcined hydrotalcite additive. J. Hazard Mater. 387, 121994.

Tokunaga, T.K., Wan, J., Pena, J., Brodie, E.L., Firestone, M.K., Hazen, T.C., Sutton, S.R., Lanzirotti, A., Newville, M., 2005. Uranium reduction in sediments under diffusion-limited transport of organic carbon. Environ. Sci. Technol. 39, 7077-7083.

Tran, H.N., Lin, C.C., Chao, H.P., 2018a. Amino acids-intercalated Mg/Al layered double hydroxides as dual-electronic adsorbent for effective removal of cationic and oxyanionic metal ions. Sep. Purif. Technol. 192, 36-45.

Tran, H.N., Lin, C.C., Woo, S.H., Chao, H.P., 2018b. Efficient removal of copper and lead by $\mathrm{Mg} / \mathrm{Al}$ layered double hydroxides intercalated with organic acid anions: adsorption kinetics, isotherms, and thermodynamics. Appl. Clay Sci. 154, 17-27.

Wan, B., Yan, Y., Huang, R., Abdala, D.B., Liu, F., Tang, Y., Tan, W., Feng, X., 2019. Formation of $\mathrm{Zn}-\mathrm{Al}$ layered double hydroxides (LDH) during the interaction of ZnO nanoparticles (NPs) with $\gamma-\mathrm{Al}_{2} \mathrm{O}_{3}$. Sci. Total Environ. 650, 1980-1987.

Wan, D., Liu, H., Liu, R., Qu, J., Li, S., Zhang, J., 2012. Adsorption of nitrate and nitrite from aqueous solution onto calcined (Mg-Al) hydrotalcite of different $\mathrm{Mg} / \mathrm{Al}$ ratio. Chem. Eng. J. 195-196, 241-247.

White, D.C., Ringelberg, D.B., 1996. Monitoring deep subsurface microbiota for assessment of safe long-term nuclear waste disposal. Can. J. Microbiol. 42, 375-381.

Xu, L., Huang, Y., 2019. A novel layered double hydroxide coupled with zero valent iron system for selenate removal under anaerobic condition: batch and continuous studies. Chem. Eng. J. 359, 1166-1174.

Xu, S., Zhang, L., Zhao, J., Cheng, J., Yu, Q., Zhang, S., Zhao, J., Qiu, X., 2020. Remediation of chromium-contaminated soil using delaminated layered double hydroxides with different divalent metals. Chemosphere 254, 126879.

Xu, Z.P., Lu, G.Q., 2005. Hydrothermal synthesis of layered double hydroxides (LDHs) from mixed $\mathrm{MgO}$ and $\mathrm{Al}_{2} \mathrm{O}_{3}$ : $\mathrm{LDH}$ formation mechanism. Chem. Mater. 17, 1055-1062.

You, Y., Vance, G.F., Zhao, H., 2001. Selenium adsorption on Mg-Al and Zn-Al layered double hydroxides. Appl. Clay Sci. 20, 13-25.

Yuan, Q., Wei, M., Wang, Z., Wang, G., Duan, X., 2004. Preparation and characterization of L-aspartic acid-intercalated layered double hydroxide. Clay Clay Miner. 52, 40-46.

Zhu, L., Zhang, L., Li, J., Zhang, D., Chen, L., Sheng, D., Yang, S., Xiao, C., Wang, J., Chai, Z., 2017. Selenium sequestration in a cationic layered rare earth hydroxide: a combined batch experiments and EXAFS investigation. Environ. Sci. Technol. 51, 8606-8615. 